\title{
Interkingdom Signal Indole Inhibits Pseudomonas aeruginosa Persister Cell Waking
}

\author{
Weiwei Zhang, Ryota Yamasaki, and Thomas K. Wood* \\ Department of Chemical Engineering, Pennsylvania State University, \\ University Park, Pennsylvania, 16802-4400, USA
}

*Correspondence: twood@engr.psu.edu

Tel.(+)1 814-863-4811; Fax (1) 814-865-7846

Running title: Indole inhibits $P$. aeruginosa waking 


\section{ABSTRACT}

2 Aims. Persister cells are stressed cells that have transient tolerance to antibiotics; these cells undergo no

3 genetic change, but instead, their tolerance is due to reduced metabolism. Unfortunately, little is known

4 about how persisters resuscitate, so we explored the waking of a cells in the presence of the interkingdom

5 signal indole. Methods and Results. To generate a large population of persister cells, we induced the

6 persister phenotype in the opportunistic pathogen Pseudomonas aeruginosa by pre-treating cells with

7 carbonyl cyanide $m$-chlorophenylhydrazone to reduce translation by depleting ATP levels, and found, via

8 single cell observations, that proline is sufficient to wake the persister cells. P. aeruginosa is often present

9 in the gastrointestinal tract, and indole from commensal bacteria such as Escherichia coli has been shown

10 to inhibit $P$. aeruginosa quorum sensing and pathogenicity without influencing growth. Furthermore,

11 indole is not toxic to $P$. aeruginosa persister cells. However, we find here that physiological concentrations of indole inhibit $P$. aeruginosa persister cell resuscitation with an efficiency of higher than 95\%. Critically, when contacted with E. coli stationary phase cultures, the indole produced by E. coli

Significance. This work provides insight into why indole is produced by commensal bacteria. 


\section{INTRODUCTION}

Persister cells become transiently tolerant to antibiotics due to metabolic dormancy, as shown by two groups in the 1940s that discovered the phenotype (Hobby et al., 1942; Bigger, 1944). Unlike resistant cells, which undergo a genetic change and grow in the presence of antibiotics, persister cells do not undergo genetic change (Kwan et al., 2015a; Chowdhury et al., 2016b). Persistence has been found in every strain tested such as Escherichia coli (Fisher et al., 2017), Pseudomonas aeruginosa (Fisher et al., 2017), Staphylococcus aureus (Fisher et al., 2017) and Archaea (Megaw and Gilmore, 2017). Also, both antibiotic and nutrient stress creates persister cells (Bernier et al., 2013; Maisonneuve and Gerdes, 2014; Martins et al., 2018). Since virtually all cells experience nutrient stress (Song and Wood, 2018) and since the viable but not culturable state appears to be the same as the persister state (Kim et al., 2018b), persistence may be a universal phenotype that is the key to microbial survival.

Stress likely activates toxins of toxin/antitoxin (TA) systems to render the metabolic dormancy of the persister state since deletion of several toxins reduces persistence (Harrison et al., 2009; Dörr et al., 2010; Kim and Wood, 2010; Luidalepp et al., 2011) and production of toxins, from TA systems (Hong et al., 2012) or toxins unrelated to TA systems (Chowdhury et al., 2016a), increases persistence dramatically. Persisters wake over a range of times from instantaneously to several hours as a function of their ribosome content (Kim et al., 2018a). However, how nutrients are perceived and how persisters resuscitate is not understood well.

The low numbers of persister cells in bacterial populations (about $1 \%$ in biofilms and stationary-phage cultures (Lewis, 2007; Lewis, 2008) hinders our understanding of these cells. We have developed methods to increase the persister cell population to nearly $100 \%$ by pre-treating with acid or hydrogen peroxide (Hong et al., 2012) as well as by halting RNA transcription via rifampicin, by stopping 
41 translation via tetracycline, and by ceasing ATP production via carbonyl cyanide

42 m-chlorophenylhydrazone (CCCP) (Kwan et al., 2013). The persister cells generated by rifampicin

43 pretreatment have been validated via eight different assays (multi-drug tolerance, immediate change from

44 persister to non-persister in the presence of nutrients, two lines of evidence for dormancy, no change in

45 the minimum inhibitory concentration compared to exponential cells, no resistance phenotype, similar

46 morphology to ampicillin-induced persisters and similar resuscitation as ampicillin-induced persisters)

47 (Kim et al., 2018a). Our chemical methods have been validated by six independent groups in recent

48 months (Grassi et al., 2017; Cui et al., 2018; Narayanaswamy et al., 2018; Sulaiman et al., 2018;

49 Tkhilaishvili et al., 2018; Pu et al., 2019) and have been shown to be effective not only for E. coli but also

50 for P. aeruginosa and S. aureus.

51 Indole is an interkingdom signal since it is produced by commensal bacteria and once it is detected

52 by epithelial cells, they use it to tighten their cell junctions to reduce infection (Bansal et al., 2010). In

53 addition, indole produced by rhizosphere bacteria stimulates Arabidopsis thaliana plant growth (Blom et

54 al., 2011), and indole has long been recognized for affecting insect behavior (Dethier, 1947). As an

55 interspecies signal, indole produced by $E$. coli reduces quorum-sensing-related virulence factors in $P$.

56 aeruginosa (Lee et al., 2009), and indole increases the competiveness of $E$. coli in dual cultures with $P$.

57 aeruginosa (Chu et al., 2012). This is significant since the opportunistic pathogen $P$. aeruginosa is better

58 known as a respiratory and wound pathogen; however, $P$. aeruginosa would experience indole since it is

59 present in the gastrointestinal (GI) tract in up to $12 \%$ of the normal population (Bodey et al., 1983), and

60 its presence in the GI tract of critically-ill surgical patients results in a nearly three-fold increase in

61 mortality (Marshall et al., 1993). 

persister cell waking without affecting its growth.

\section{METHODS}

69 Bacteria and culture conditions. Strains (Table 1) were grown routinely in LB medium (Sambrook,

70 1989) at $37^{\circ} \mathrm{C}$. M9 minimal medium was supplemented with different amino acids (Rodriguez., 1983).

71 M9-casamino acid tryptophan was prepared as described previously ( $\mathrm{Li}, 2013)$ and used for indole

72 production. CCCP was dissolved in DMSO at stock a concentration of $50 \mathrm{mg} / \mathrm{mL}$. Indole was dissolved

73 in dimethyl sulfoxide at a stock concentration of $1 \mathrm{M}$.

74 Persister cells. PA14 persister cells were generated by stopping ATP production with CCCP (Kwan et

75 al., 2013) and by lysing non-dormant cells with ciprofloxacin. One milliliter of overnight PA14 culture

76 was diluted in $5 \mathrm{~mL}$ of fresh LB with $24 \mu \mathrm{L}$ of CCCP stock solution (final concentration $200 \mu \mathrm{g} / \mathrm{mL}$ ) and incubated for $3 \mathrm{~h}$. Bacteria were washed with $0.85 \% \mathrm{NaCl}(3500 \times \mathrm{g}$ for $10 \mathrm{~min})$, resuspended in $\mathrm{LB}$ supplemented with ciprofloxacin $(5 \mu \mathrm{g} / \mathrm{mL})$ for $3 \mathrm{~h}$ to lyse non-persister cells, then washed twice with $0.85 \% \mathrm{NaCl}$. 
$84 \quad$ PA14 resuscitation with amino acids. To observe resuscitation of $P$. aeruginosa PA14 (hereafter PA14)

85 persister cells with amino acids as the sole carbon source, amino acids were initially divided into four

86 combinations of five each in M9 minimal medium: combination \#1: Arg, Ser, Cys, Ala and Phe,,

87 combination \#2: His, Thr, Gly, Val, and Tyr, combination \#3:Lys, Asn, Pro, Ile, and Trp, and

88 combination \#4:Asp, Glu, Gln, Leu, and Met. To observe the resuscitation of persister cells on single

89 amino acids, the 15 amino acids from combinations 2, 3, and 4 were tested separately. PA14 persister

90 cells were diluted 5000-fold, and $50 \mu \mathrm{L}$ was spread onto M9 plates containing each kind of individual

91 amino acid.

92 Single cell resuscitation. To observe the resuscitation of single cells, agarose gel pads were used (Kim et

93 al., 2018a). Briefly, low melting agarose (1.5\%) (Nusieve GTG agarose BMB \# 50081) was added to 11

$94 \mathrm{~mL} \mathrm{H}_{2} \mathrm{O}$ and melted by microwaving (30 sec at 1,500 Watts), and $1.25 \mathrm{~mL} 10 \times$ salt solution $(0.125 \mathrm{~mL}$

$95 \mathrm{MgSO}_{4}$ and $\left.\left.0.125 \mathrm{~mL} \mathrm{CaCl}\right)_{2}\right)$ with proline $(0.164 \mathrm{mg} / \mathrm{mL})$ was added after cooling. Single cells were

96 observed using light microscope (Zeiss Axioscope.A1, bl_ph channel at 1,000 ms exposure) maintained

97 at $37^{\circ} \mathrm{C}$.

P. aeruginosa resuscitation in the presence of $\boldsymbol{E}$. coli. PA14 persister cells (1 mL) were added to $25 \mathrm{~mL}$ cultures of BW25113 grown in M9 casamino acids tryptophan medium for 24 hrs. The mixtures were incubated at $37{ }^{\circ} \mathrm{C}$ with shaking and samples taken after $5 \mathrm{~min}, 30 \mathrm{~min}, 60 \mathrm{~min}$ and $120 \mathrm{~min}$. Cells were diluted $10^{4}$ - to $10^{6}$ - fold, washed twice with $0.85 \% \mathrm{NaCl}$, and plated on LB plates. PA14 and BW25113 to ampicillin). 


\section{RESULTS}

106 CCCP-induces PA14 persister formation. In order to study PA14 resuscitation, we first optimized conditions for PA14 persister cell formation, using methods we developed for E. coli to reduce ATP and thereby induce the dormant state (Kwan et al., 2013). We found that $200 \mu \mathrm{g} / \mathrm{mL}$ pretreatment with CCCP for $3 \mathrm{~h}$ induced PA14 persister cell formation with an efficiency of $98.6 \%$ as evidenced by their ciprofloxacin tolerance (Fig. S1). To verify that these cells are bona fide persister cells, we completed three additional assays and found (i) re-grown persister cells have the same sensitivity to the antibiotic (5 $\mu \mathrm{g} / \mathrm{mL}$ ciprofloxacin, Fig. S2), (ii) CCCP-generated persisters show the same minimal inhibitory concentration as the wild type PA14 (Fig. S3), and (iii) 99.3\% of the PA14 persister cells obtained from CCCP-pretreatment do not resuscitate in $10 \mathrm{~h}$ on agarose pads lacking nutrients ( 1 cell out of 228 resuscitate) (Fig. 1A) whereas 100\% of exponentially-grown PA14 cells resuscitate on gel pads without any carbon source (Fig. 1B). Therefore, CCCP-pretreatment induces PA14 into the persister state with high efficiency.

PA14 persister cells resuscitate on proline. Having established how to generate PA14 persister cells, we investigated whether a single amino acid wakes PA14 persisters since alanine revives Bacillus subtilis spores (Mutlu et al., 2018); our hypothesis is that dormant PA14 persister cells wake like dormant spores. and Phe, combination \#2: His, Thr, Gly, Val, and Tyr, combination \#3:Lys, Asn, Pro, Ile, and Trp, and combination \#4:Asp, Glu, Gln, Leu, and Met. Using an agar plate assay in which persister cells that wake 
127 S4 and Table S1). We then proceeded to separately test each of the 15 amino acids from combinations \#2,

$128 \# 3$ and \#4, and found PA14 persister cells wake fastest with proline as the sole carbon source (Fig. 2).

129 Using observations of single cells waking on proline, we found that $88 \%$ of the PA14 persisters revive in

$13010 \mathrm{~h}$ on M9 proline agar plates (Fig. 3).

131 Indole inhibits PA14 persister cell waking. Since indole inhibits the virulence of $P$. aeruginosa (Lee et

132 al., 2016), we hypothesized that indole may affect the resuscitation of PA14 persister cells. We found that

133 when $2 \mathrm{mM}$ indole is present, it inhibits the waking of more than 95\% of the PA14 persister cells (Fig.

134 S5). Corroborating this result with single cells, we found 99\% of PA14 persister cells were inhibited after

$13510 \mathrm{~h}$ on $\mathrm{M} 9$ proline plates containing $2 \mathrm{mM}$ indole (Fig. 4). Critically, $2 \mathrm{mM}$ indole was not toxic to

136 PA14 persister cells (Fig. S6) (the specific growth rate was reduced only by 5.8\%) so the inhibition of

137 PA14 persister cell resuscitation was not due to growth inhibition. Indole was also not toxic to BW25113

138 persister cells and unlike PA14, indole had no inhibitory effect on the wake up of BW25113 persister

139 cells (Fig. S7).

140 BW25113 producing indole outcompetes PA14. BW25113 grown in M9 casamino acids tryptophan

141 medium produced $4.6 \mathrm{mM}$ indole in the culture supernatant after $24 \mathrm{~h}$, while no indole was produced by

142 the E. coli BW25113 $\Delta$ tnaA since it lacks tryptophanase (Table S2). When PA14 persister cells were

143 added to the BW25113 cells grown in this medium, no PA14 persister cells resuscitated. Without indole,

$14497.1 \%, 93.4 \%, 98.8 \%$, and $98.7 \%$ of the PA14 persister cells resuscitated in the E. coli $\Delta$ tnaA culture

after 5, 30, 60, and 120 min (Fig. 5). Hence, indole produced by E. coli prevents $P$. aeruginosa persister

cells from resuscitating. 
148

149

150

151

152

153

154

155

156

157

158

159

160

161

162

163

164

165

166

167

\section{DISCUSSION}

By preventing protein production via a CCCP pretreatment followed by contacting with ciprofloxacin to lyse any non-dormant cells, we converted $P$. aeruginosa cultures into nearly homogeneous persister cell populations; hence, we converted the rare persister phenotype (less than 1\%) into the dominant phenotype. By using this approach, we were able to determine that $P$. aeruginosa persister cells can be resuscitated by the amino acid proline. Building on this discovery, we were able to determine a new physiological role for the interkingdom signal indole: E. coli cells in the GI tract produce indole to not only tighten human epithelial cell junctions (Bansal et al., 2010) but indole is also produced by commensal $E$. coli to prevent $P$. aeruginosa persister cells from resuscitating.

This discovery of indole inhibiting $P$. aeruginosa persister cell waking is physiologically relevant since P. aeruginosa is found in the GI tract (Bodey et al., 1983; Marshall et al., 1993), and cells in the GI tract experience nutritional stress between meals. This stress likely leads to the formation of $P$. aeruginosa persister cells in the GI tract. Therefore, our results suggest that indole is produced by E. coli as a tool to prevent $P$. aeruginosa cells from waking so that $E$. coli cells may outcompete $P$. aeruginosa cells for limited nutrients by resuscitating first.

\section{ACKNOWLEDGEMENTS}

This work was supported by funds derived from the Biotechnology Endowed Professorship at the Pennsylvania State University. This work also was supported by National Natural Science Foundation of China (41676141), the China Scholarship Council (1712290032) and the K.C. Wong Magna Fund at Ningbo University, China. The authors confirm there are no conflicts of interest. 


\section{REFERENCES}

\section{Baba T, A.T., Hasegawa M, Takai Y, Okumura Y, Baba M, Datsenko KA, Tomita M, Wanner BL,}

Mori H. . 2006. Construction of Escherichia coli K-12 in frame, single-gene knockout mutants: the Keio collection. . Mol Syst Biol 445

Bansal, T., Alaniz, R.C., Wood, T.K., and Jayaraman, A. 2010. The bacterial signal indole promotes epithelial cell barrier properties and attenuates inflammation. PNAS 107, 228-233.

Bernier, S.P., Lebeaux, D., DeFrancesco, A.S., Valomon, A., Soubigou, G., Coppee, J.Y. et al. 2013. Starvation, together with the SOS response, mediates high biofilm-specific tolerance to the fluoroquinolone ofloxacin. PLoS Genet 9, e1003144.

Bigger, J.W. 1944. Treatment of staphylococcal infections with penicillin - By intermittent sterilisation.

Lancet 2, 497-500.

Blom, D., Fabbri, C., Connor, E.C., Schiestl, F.P., Klauser, D.R., Boller, T. et al. 2011. Production of plant growth modulating volatiles is widespread among rhizosphere bacteria and strongly depends on culture conditions. Environmental Microbiology 13, 3047-3058.

Bodey, G.P., Bolivar, R., Fainstein, V., and Jadeja, L. 1983. Infections caused by Pseudomonas aeruginosa. Rev Infect Dis 5, 279-313.

Chowdhury, N., Kwan, B.W., and Wood, T.K. 2016a. Persistence Increases in the Absence of the Alarmone Guanosine Tetraphosphate by Reducing Cell Growth. Scientific Reports 6.

Chowdhury, N., Wood, T.L., Martinez-Vazquez, M., Garcia-Contreras, R., and Wood, T.K. 2016 b. DNA-crosslinker cisplatin eradicates bacterial persister cells. Biotechnol Bioeng 113， 1984-1992. 
Chu, W., Zere, T.R., Weber, M.M., Wood, T.K., Whiteley, M., Hidalgo-Romano, B. et al. 2012.

Indole Production Promotes Escherichia coli Mixed-Culture Growth with Pseudomonas aeruginosa by Inhibiting Quorum Signaling. Applied and Environmental Microbiology 78, 411-419.

Cui, P., Niu, H., Shi, W., Zhang, S., Zhang, W., and Zhang, Y. 2018. Identification of Genes Involved in Bacteriostatic Antibiotic-Induced Persister Formation. Front Microbiol 9, 413.

Dethier, V.G. 1947. Chemical insect attractants and repellents. Philadelphia: Blakiston Co.

Dörr, T., Vulić, M., and Lewis, K. 2010. Ciprofloxacin causes persister formation by inducing the TisB toxin in Escherichia coli. PLoS Biol 8, e1000317.

Fisher, R.A., Gollan, B., and Helaine, S. 2017. Persistent bacterial infections and persister cells. Nature Reviews Microbiology 15, 453-464.

Grassi, L., Di Luca, M., Maisetta, G., Rinaldi, A.C., Esin, S., Trampuz, A., and Batoni, G. 2017. Generation of Persister Cells of Pseudomonas aeruginosa and Staphylococcus aureus by Chemical Treatment and Evaluation of Their Susceptibility to Membrane-Targeting Agents. Front Microbiol 8, 1917.

Harrison, J.J., Wade, W.D., Akierman, S., Vacchi-Suzzi, C., Stremick, C.A., Turner, R.J., and Ceri, H. 2009. The chromosomal toxin gene yafQ is a determinant of multidrug tolerance for Escherichia coli growing in a biofilm. Antimicrob Agents Chemother 53, 2253-2258.

Hobby, G.L., Meyer, K., and Chaffee, E. 1942. Observations on the mechanism of action of penicillin. Proceedings of the Society for Experimental Biology and Medicine 50, 281-285.

Hong, S.H., Wang, X., O'Connor, H.F., Benedik, M.J., and Wood, T.K. 2012. Bacterial persistence increases as environmental fitness decreases. Microbial Biotechnol 5, 509-522. 
Hu, Y., Kwan, B.W., Osbourne, D.O., Benedik, M.J., and Wood, T.K. 2015. Toxin YafQ increases persister cell formation by reducing indole signalling. Environ Microbiol 17, 1275-1285.

Kim, J.-S., Yamasaki, R., Song, S., Zhang, W., and Wood, T.K. 2018a. Single cell observations show persister cells wake based on ribosome content. Environmental Microbiology in press.

Kim, J.S., Chowdhury, N., Yamasaki, R., and Wood, T.K. 2018b. Viable but non-culturable and persistence describe the same bacterial stress state. Environ Microbiol.

Kim, Y., and Wood, T.K. 2010. Toxins Hha and CspD and small RNA regulator Hfq are involved in persister cell formation through MqsR in Escherichia coli. Biochem Biophys Res Commun 391, 209-213.

Kwan, B.W., Chowdhury, N., and Wood, T.K. 2015a. Combatting bacterial infections by killing persister cells with mitomycin C. Environ Microbiol 17, 4406-4414.

Kwan, B.W., Valenta, J.A., Benedik, M.J., and Wood, T.K. 2013. Arrested protein synthesis increases persister-like cell formation. Antimicrob Agents Chemother 57, 1468-1473.

Kwan, B.W., Osbourne, D.O., Hu, Y., Benedik, M.J., and Wood, T.K. 2015b. Phosphodiesterase DosP increases persistence by reducing cAMP which reduces the signal indole. Biotechnology and Bioengineering 112, 588-600.

Lee, J.-H., Kim, Y.-G., Gwon, G., Wood, T.K., and Lee, J. 2016. Halogenated indoles eradicate bacterial persister cells and biofilms. AMB Express 6, 123.

Lee, J., Attila, C., Cirillo, S.L.G., Cirillo, J.D., and Wood, T.K. 2009. Indole and 7-hydroxyindole diminish Pseudomonas aeruginosa virulence. Microbial Biotech 2, 75-90.

Lewis, K. 2007. Persister cells, dormancy, and infectious disease. Nat Rev Microbiol 5, 48-56. 
Lewis, K. 2008. Multidrug tolerance of biofilms and persister cells. Curr Top Microbiol Immunol 322, $107-131$.

Li, G.a.K.D.Y. 2013. Indole production by the tryptophanase TnaA in Escherichia coli is determined by the amount of exogenous tryptophan. Microbiology-Sgm 159, 9.

Liberati, N.T., J. M. Urbach, S. Miyata, D. G. Lee, E. Drenkard, G. Wu, et al. . 2006. . An ordered, nonredundant library of Pseudomonas aeruginosa strain PA14 transposon insertion mutants. . Proc Natl Acad Sci USA 103, 6.

Luidalepp, H., Jõers, A., Kaldalu, N., and Tenson, T. 2011. Age of Inoculum Strongly Influences Persister Frequency and Can Mask Effects of Mutations Implicated in Altered Persistence. Journal of Bacteriology 193, 3598-3605.

Maisonneuve, E., and Gerdes, K. 2014. Molecular mechanisms underlying bacterial persisters. Cell 157, 539-548.

Marshall, J.C., Christou, N.V., and Meakins, J.L. 1993. The gastrointestinal tract. The "undrained abscess" of multiple organ failure. Ann Surg 218, 111-119.

Martins, P.M.M., Merfa, M.V., Takita, M.A., and De Souza, A.A. 2018. Persistence in Phytopathogenic Bacteria: Do We Know Enough? Frontiers in Microbiology 9.

Megaw, J., and Gilmore, B.F. 2017. Archaeal Persisters: Persister Cell Formation as a Stress Response in Haloferax volcanii. Frontiers in Microbiology 8.

Mutlu, A., Trauth, S., Ziesack, M., Nagler, K., Bergeest, J.P., Rohr, K. et al. 2018. Phenotypic memory in Bacillus subtilis links dormancy entry and exit by a spore quantity-quality tradeoff. Nature Communications 9. 
Narayanaswamy, V.P., Keagy, L.L., Duris, K., Wiesmann, W., Loughran, A.J., Townsend, S.M., and Baker, S. 2018. Novel Glycopolymer Eradicates Antibiotic- and CCCP-Induced Persister Cells in Pseudomonas aeruginosa. Front Microbiol 9, 1724.

Pu, Y., Li, Y., Jin, X., Tian, T., Ma, Q., Zhao, Z. et al. 2019. ATP-Dependent Dynamic Protein Aggregation Regulates Bacterial Dormancy Depth Critical for Antibiotic Tolerance. Molecular Cell 73, $1-14$.

Rodriguez., R. 1983. Recombinant DNA Techniques: An Introduction. 3rd Paperback Edition Edition. Addison-Wesley; 3rd Paperback Edition edition (October 1, 1983).

Sambrook, J., E. F. Fritsch, and T. Maniatis. . 1989. Molecular cloning: a laboratory manual, 2nd ed. . Cold Spring Harbor Laboratory Press, Cold Spring Harbor, NY.

Song, S., and Wood, T.K. 2018. Post-segregational Killing and Phage Inhibition Are Not Mediated by Cell Death Through Toxin/Antitoxin Systems. Front Microbiol 9, 814.

Sulaiman, J.E., Hao, C., and Lam, H. 2018. Specific Enrichment and Proteomics Analysis of Escherichia coli Persisters from Rifampin Pretreatment. J Proteome Res 17, 3984-3996.

Tkhilaishvili, T., Lombardi, L., Klatt, A.-B., Trampuz, A., and Di Luca, M. 2018. Bacteriophage Sb-1 enhances antibiotic activity against biofilm, degrades exopolysaccharide matrix and targets persisters of Staphylococcus aureus. Int J Antimicrob Agents 52, 842-853. 
Table 1. Strains used in this study.

\begin{tabular}{ccc}
\hline Strain & Relevant characteristics & Source \\
\hline P. aeruginosa PA14 & wild type & (Liberati, 2006 ) \\
E. coli $\mathrm{BW} 25113$ & $\operatorname{lacl}^{\mathrm{q}} r r n B_{\mathrm{T} 14} \Delta l a c Z_{\mathrm{WJ} 16} h s d R 514 \Delta a r a B A D_{\mathrm{AH} 33}$ & $($ Baba T, 2006) \\
& $\Delta r h a B A D_{\mathrm{LD} 78}$ & \\
BW25113 $\Delta t n a A$ & $\Delta t n a A \square \mathrm{Km}^{\mathrm{R}}$ & $($ Baba T, 2006) \\
\hline
\end{tabular}




\section{FIGURE CAPTIONS}

Fig. 1. PA14 persister cell waking in the absence of a carbon source. (A) Resuscitation of single PA14 persister cells on M9 medium gel pads that lack a carbon source after $10 \mathrm{~h}$. (B) As a positive control, exponentially-grown PA14 cells were tested for resuscitation after $4 \mathrm{~h}$ in the absence of a carbon source. Scale bar indicates $10 \mu \mathrm{m}$. One of two independent cultures shown.

Fig. 2. PA14 persister cell waking on single amino acids. Resuscitation of PA14 persister cells after $48 \mathrm{~h}$ at $37^{\circ} \mathrm{C}$ on $\mathrm{M} 9$ agar medium with 15 individual amino acids.

Fig. 3. PA14 persister cell waking on proline. Resuscitation of single PA14 persister cells after $10 \mathrm{~h}$ at $37^{\circ} \mathrm{C}$ on $\mathrm{M} 9$ proline agarose pads. The white indicates one of the first cells to resuscitate. Scale bar indicates $10 \mu \mathrm{m}$. One of two independent cultures shown.

Fig. 4. Indole inhibits PA14 persister cell waking on proline. Resuscitation of single PA14 persister cells after $10 \mathrm{~h}$ on $\mathrm{M} 9$ proline $+2 \mathrm{mM}$ indole agarose gel pads. Scale bar indicates $10 \mu \mathrm{m}$. One of two independent cultures shown.

Fig. 5. Indole gives $E$. coli a competitive advantage over PA14. PA14 persister cells were contacted with E. coli BW25113 wild type (A) and with E. coli BW25113 $\Delta$ tnaA (B) M9 casamino acids tryptophan medium cultures for 5, 30, 60 and 120 min, then samples were added to LB plates that were incubated at $37^{\circ} \mathrm{C}$ for 16 hours. 
bioRxiv preprint doi: https://doi.org/10.1101/674978; this version posted June 18, 2019. The copyright holder for this preprint (which was not certified by peer review) is the author/funder, who has granted bioRxiv a license to display the preprint in perpetuity. It is made available under aCC-BY-NC-ND 4.0 International license.

(A)

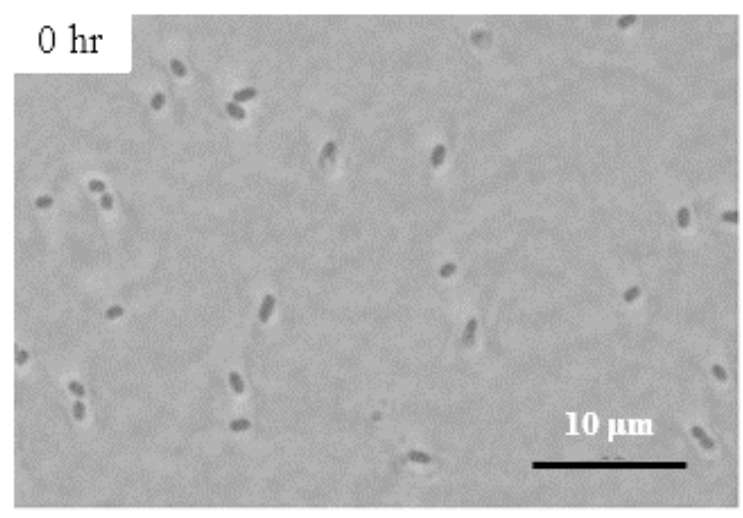

(B)

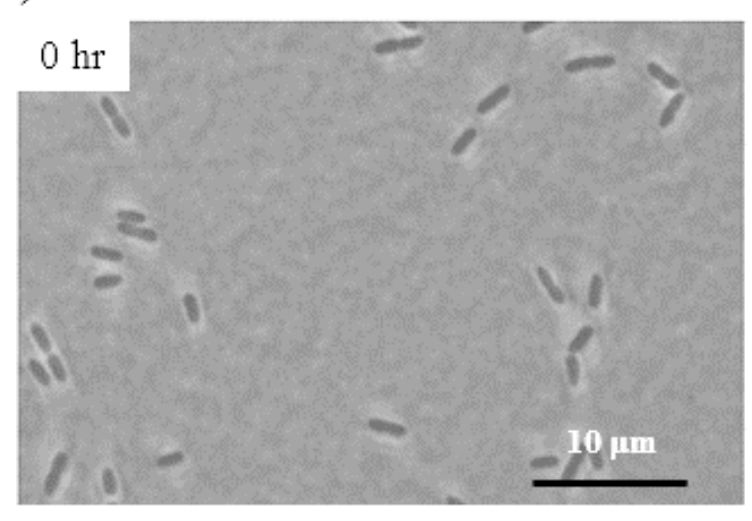

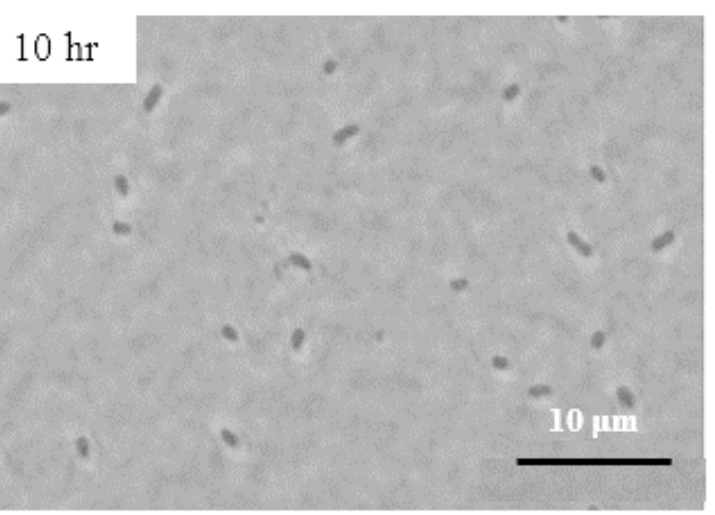

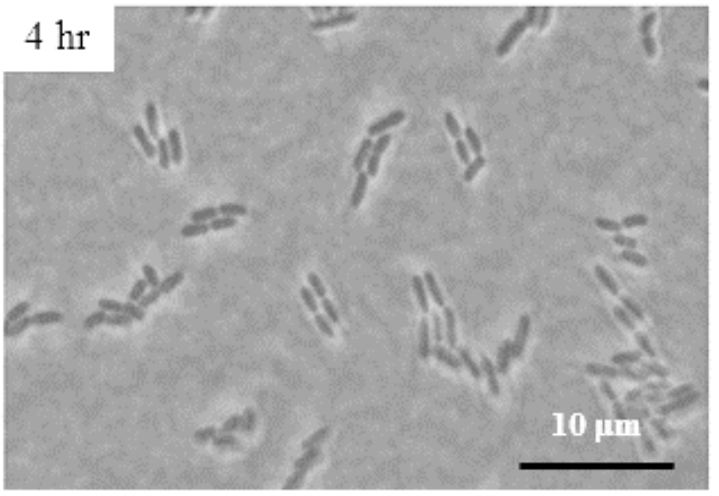

\section{Figure 1}


bioRxiv preprint doi: https://doi.org/10.1101/674978; this version posted June 18,2019. The copyright holder for this preprint (which was not certified by peer review) is the author/funder, who has granted bioRxiv a license to display the preprint in perpetuity. It is made available under aCC-BY-NC-ND 4.0 International license.
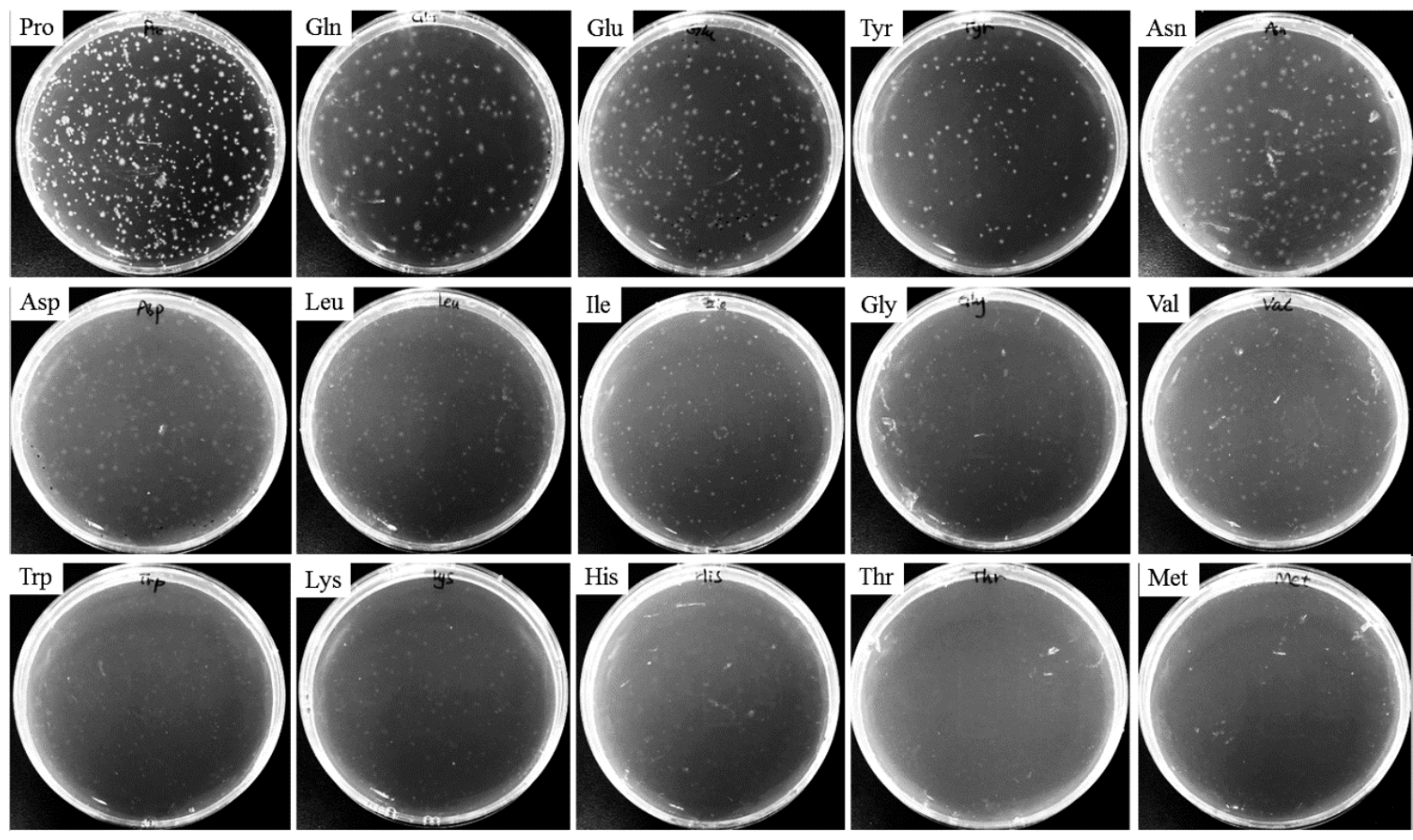

Figure 2 
bioRxiv preprint doi: https://doi.org/10.1101/674978; this version posted June 18, 2019. The copyright holder for this preprint (which was not certified by peer review) is the author/funder, who has granted bioRxiv a license to display the preprint in perpetuity. It is made available under aCC-BY-NC-ND 4.0 International license.
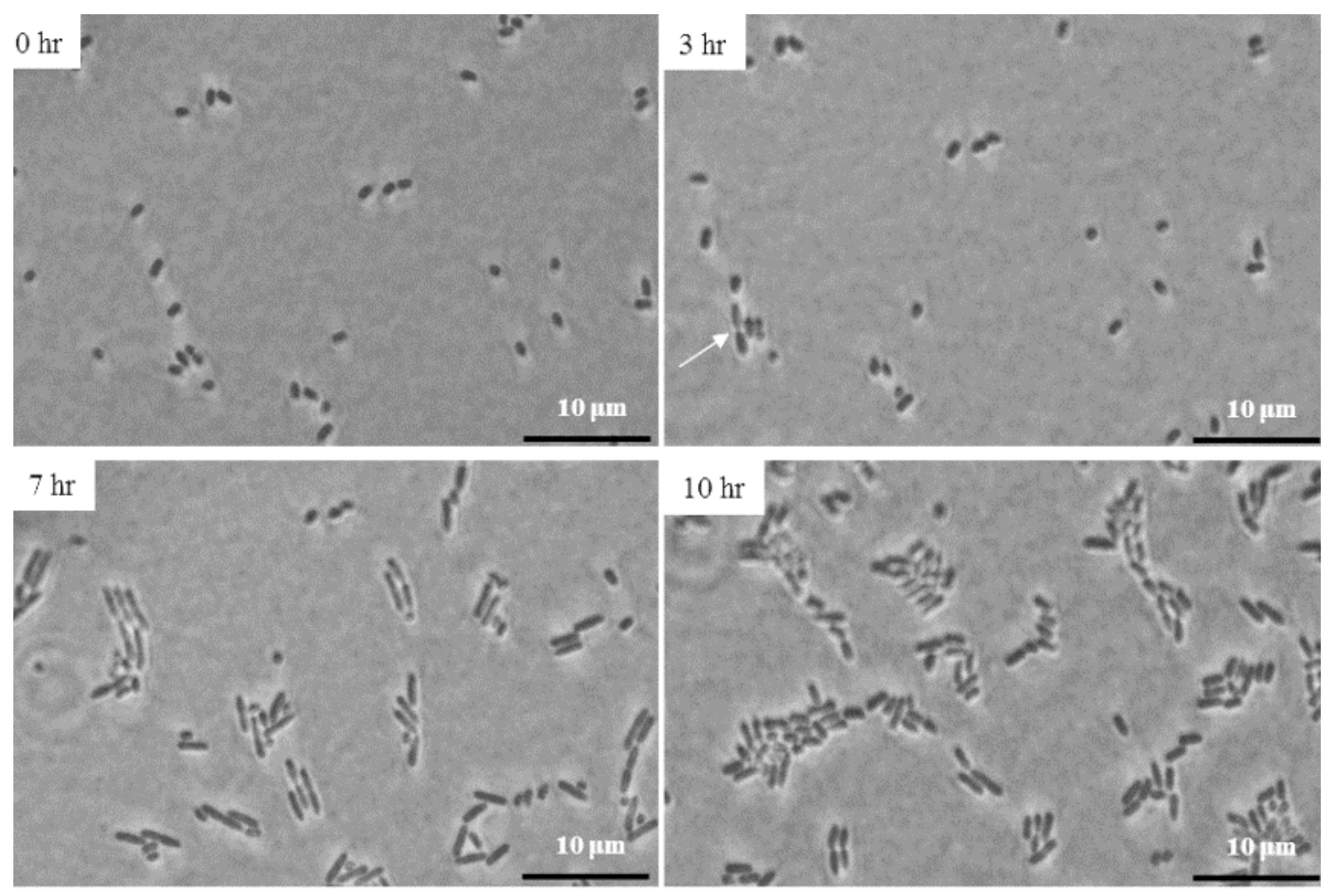

Figure 3 
bioRxiv preprint doi: https://doi.org/10.1101/674978; this version posted June 18, 2019. The copyright holder for this preprint (which was not certified by peer review) is the author/funder, who has granted bioRxiv a license to display the preprint in perpetuity. It is made available under aCC-BY-NC-ND 4.0 International license.
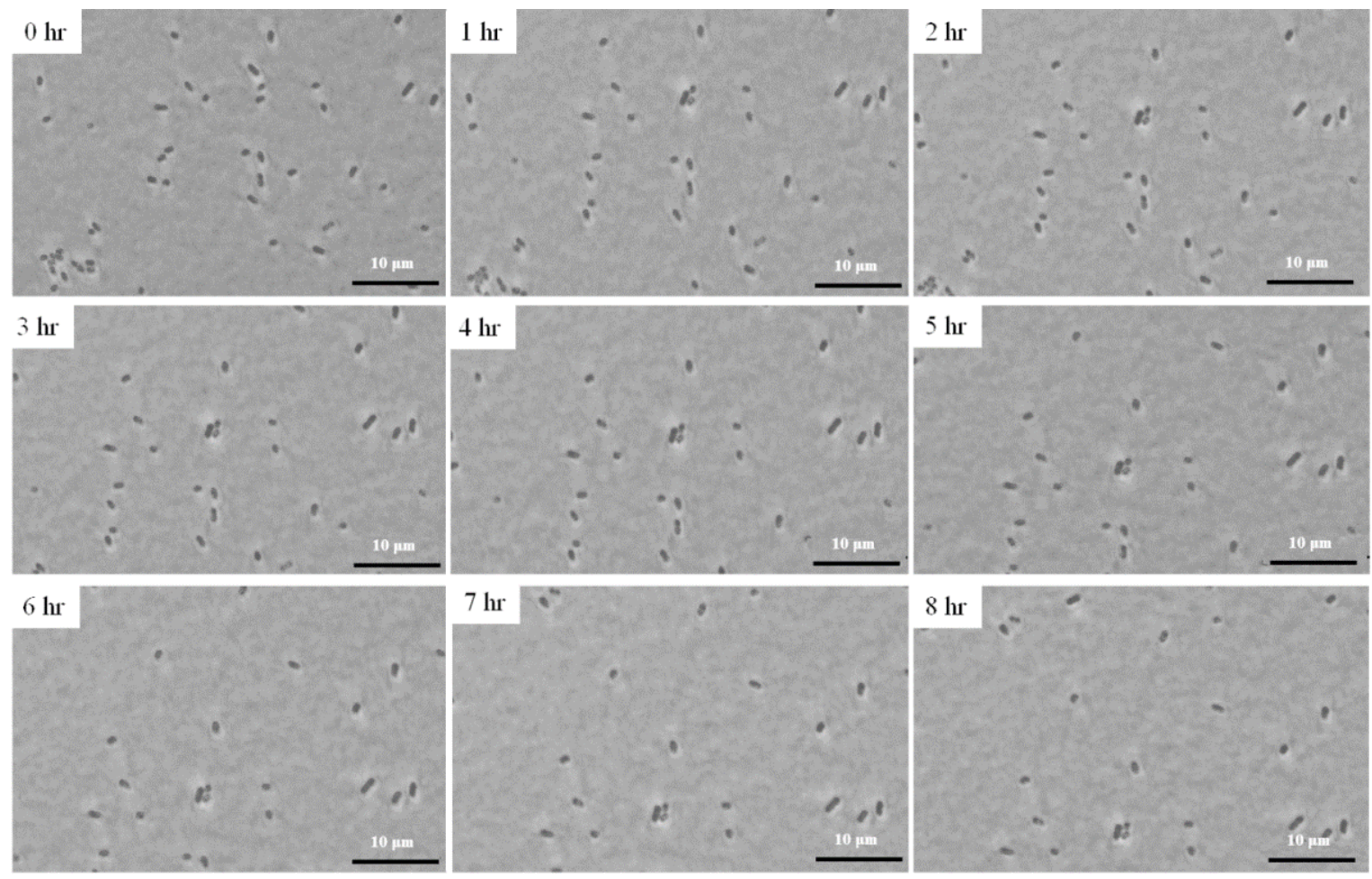

\section{Figure 4}


bioRxiv preprint doi: https://doi.org/10.1101/674978; this version posted June 18, 2019. The copyright holder for this preprint (which was not certified by peer review) is the author/funder, who has granted bioRxiv a license to display the preprint in perpetuity. It is made available under aCC-BY-NC-ND 4.0 International license.
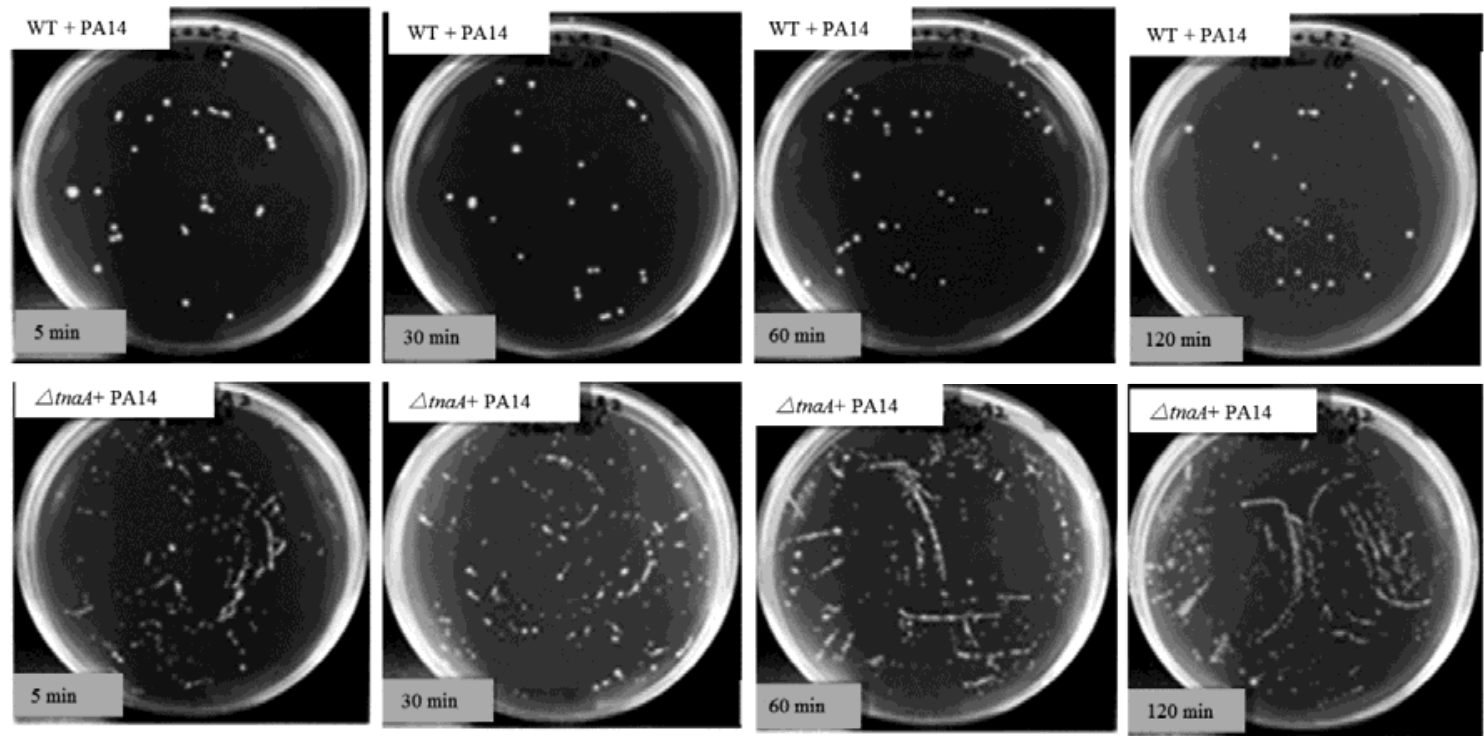

Figure 5 


\title{
Supporting Information
}

\section{Interkingdom Signal Indole Inhibits Pseudomonas aeruginosa Persister Cell Waking}

\author{
Weiwei Zhang, Ryota Yamasaki, and Thomas K. Wood \\ Department of Chemical Engineering, Pennsylvania State University, \\ University Park, Pennsylvania, 16802-4400, USA
}

*Correspondence: twood@engr.psu.edu

Tel.(+)1 814-863-4811; Fax (1) 814-865-7846 
Table S1. PA14 persister resuscitation on M9 minimal agar plates with groups of five amino acids.

Colonies were counted after 24 and $48 \mathrm{~h}$.

\begin{tabular}{ccc}
\hline $\begin{array}{c}\text { Amino acid } \\
\text { combination }\end{array}$ & $\begin{array}{c}\text { Colony number } \\
\mathbf{( 2 4} \mathbf{~})\end{array}$ & $\begin{array}{c}\text { Colony number } \\
\mathbf{( 4 8} \mathbf{~})\end{array}$ \\
\hline No amino acid & 0 & 0 \\
$\# 1$ & 0 & 0 \\
$\# 2$ & $30 \pm 16$ & $49 \pm 25$ \\
$\# 3$ & $44 \pm 17$ & $74 \pm 16$ \\
$\# 4$ & $18 \pm 1$ & $53 \pm 21$ \\
\hline
\end{tabular}


Table S2. Indole produced by $E$. coli BW25113 in in M9 casamino acids tryptophan medium. Cells were cultured for $24 \mathrm{~h}$, and the turbidity at $600 \mathrm{~nm}$ is indicated. Two independent cultures were used (labeled as \#1 and \#2).

\begin{tabular}{ccc}
\hline Samples & Turbidity & $\begin{array}{c}\text { Indole in supernatant } \\
(\boldsymbol{\mu M})\end{array}$ \\
\hline WT \#1 & 3.6 & $501 \pm 40$ \\
WT \#2 & 3.3 & $448 \pm 5$ \\
$\Delta$ tnaA \#1 & 3.7 & 0 \\
$\Delta$ tnaA \#2 & 3.5 & 0 \\
\hline
\end{tabular}



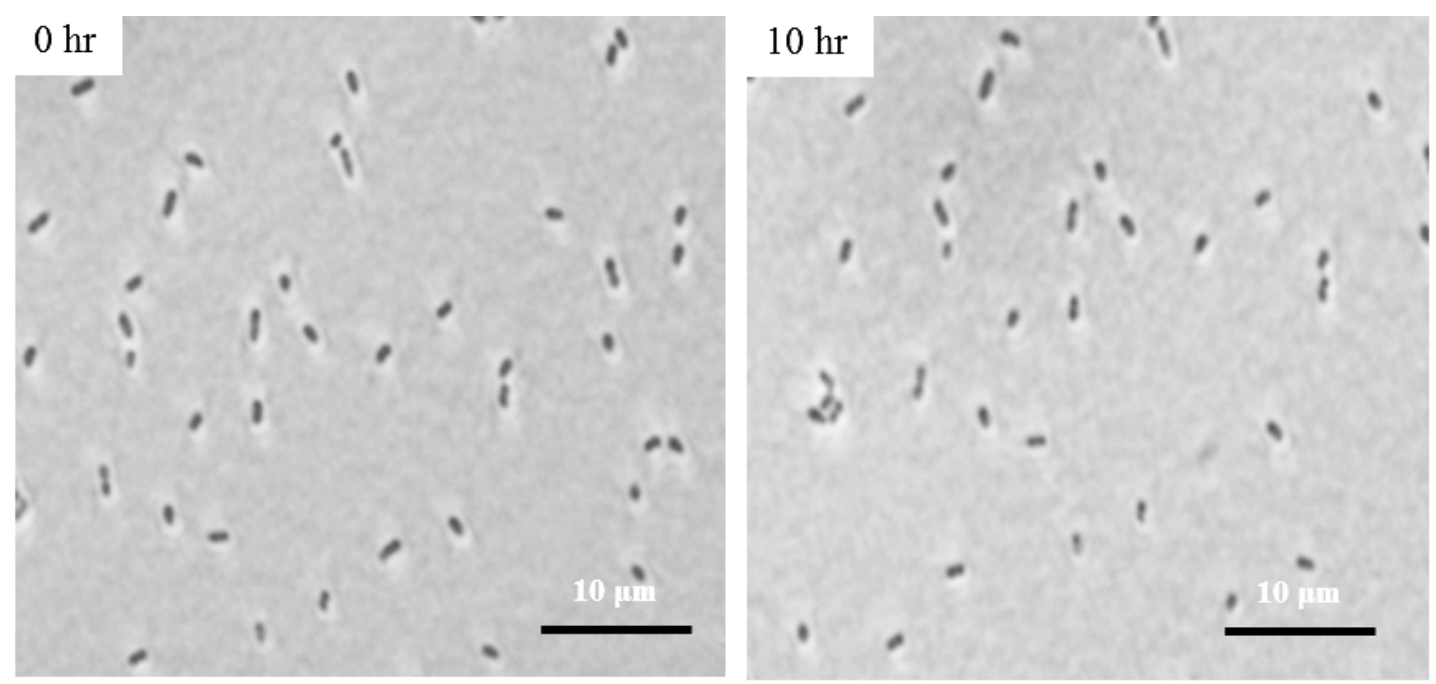

Fig. S1. CCCP-generated $P$. aeruginosa PA14 persister cells are tolerant to ciprofloxacin. Persister cells on the M9 gel pads (no amino acids) with ciprofloxacin do not lyse in $10 \mathrm{~h}$. For the two independent cultures, 1 out of 122 cells woke (i.e., elongated and died due to the antibiotic) and 1 out of 191 cells woke. One representative sample shown. 


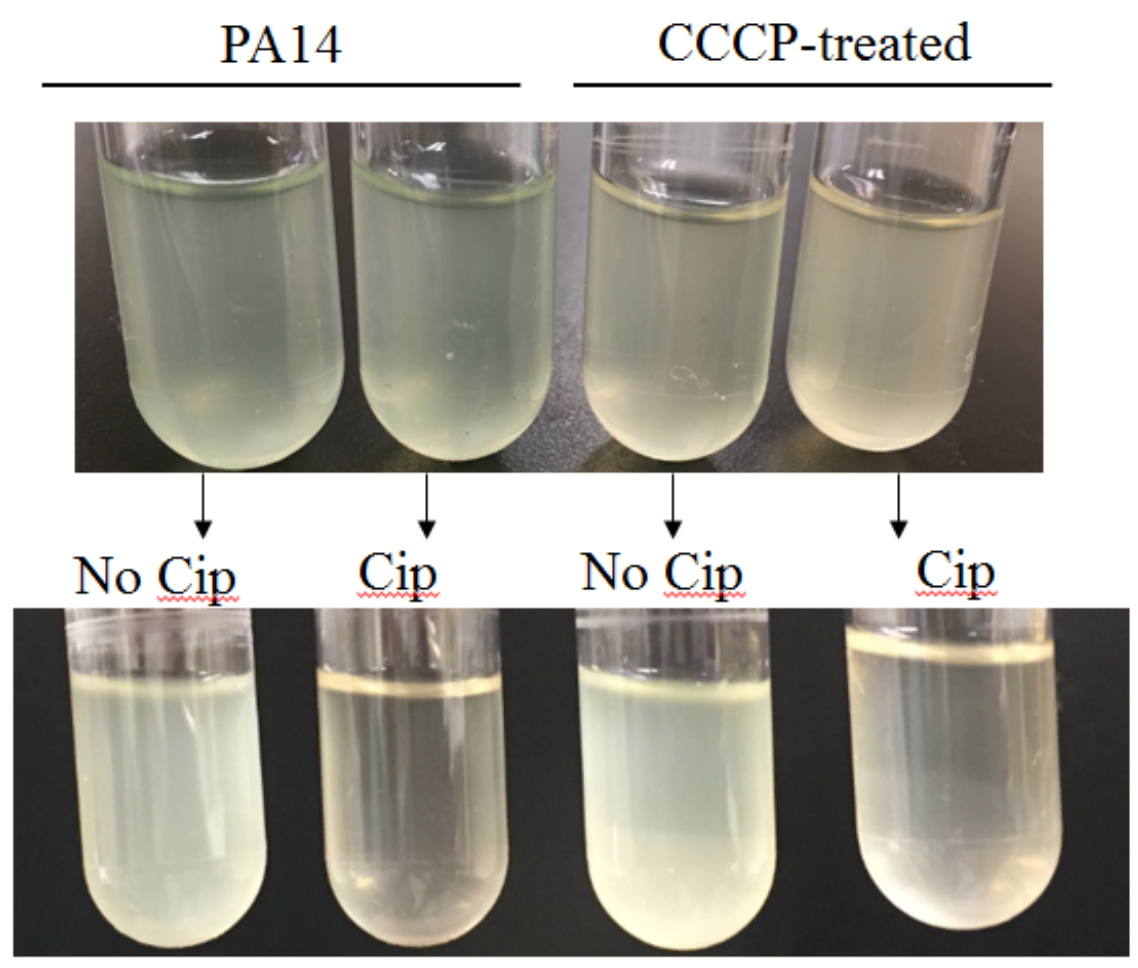

Fig. S2. CCCP-generated $P$. aeruginosa PA14 persister cells have the same antibiotic tolerance as wild-type cells. After re-growth in LB medium, CCCP-generated persister cells are lysed by 5 $\mu \mathrm{g} / \mathrm{mL}$ ciprofloxacin in the same manner as wild-type PA14 cells. 


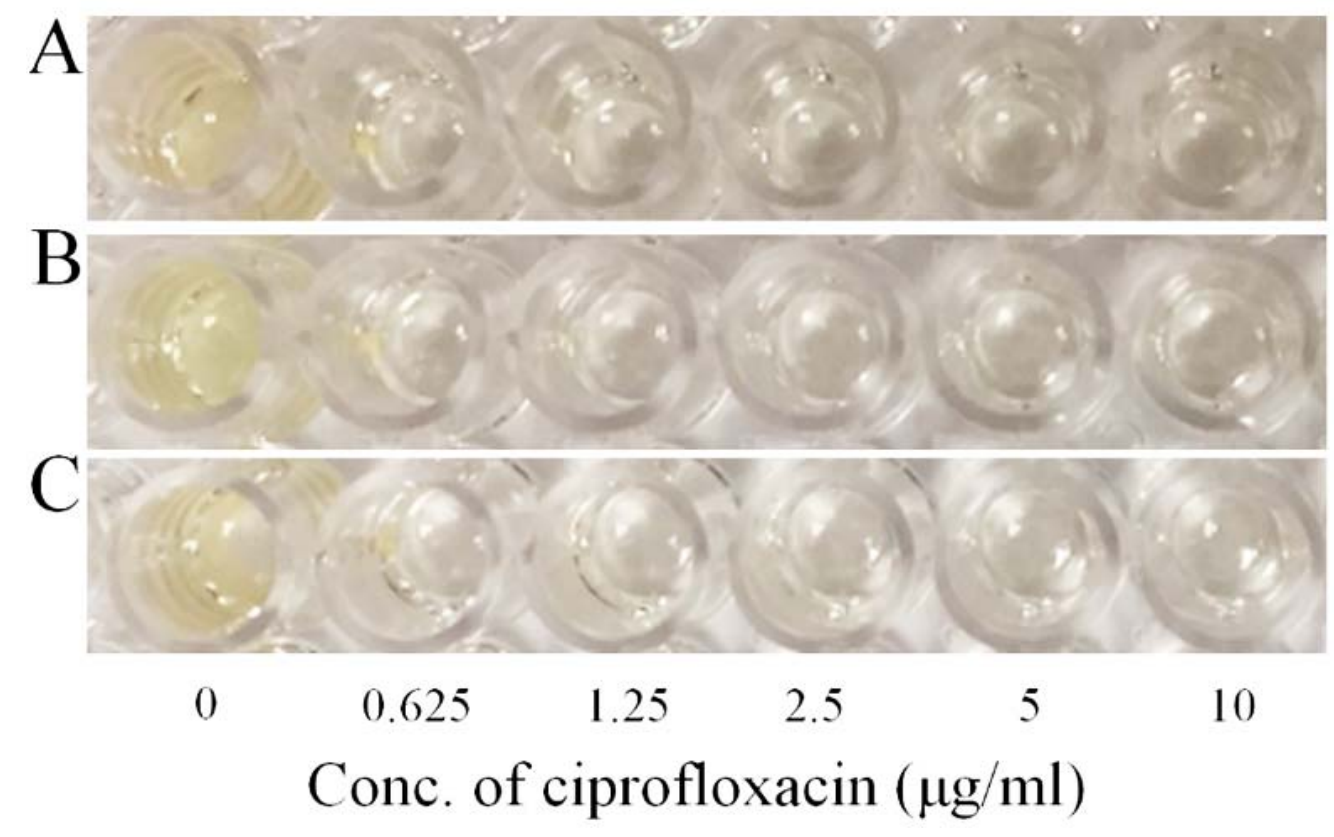

Fig. S3. CCCP-generated $P$. aeruginosa PA14 persister cells have the same minimum inhibitory concentration as wild-type cells. Overnight cultures of PA14 at turbidity 4.0 (A), CCCP-induced persister cells at turbidity 3.6 (without ciprofloxacin treatment) (B), and re-grown CCCP-induced persisters at turbidy 2.5(C) were diluted into fresh LB at a concentration of $10^{4}$ cells $/ \mathrm{mL}$. Cells $(196 \mu \mathrm{L})$ were placed in 96-well plates, and ciprofloxacin was added in $4 \mu \mathrm{L}$. The final concentrations of ciprofloxacin were $0,0.625,1.25,2.5,5$, and 10 $\mu \mathrm{g} / \mathrm{ml}$ as indicated. The 96 -well plates were incubated at $37{ }^{\circ} \mathrm{C}$ for overnight, and the concentration at which cells did not grow was used as the MIC. 


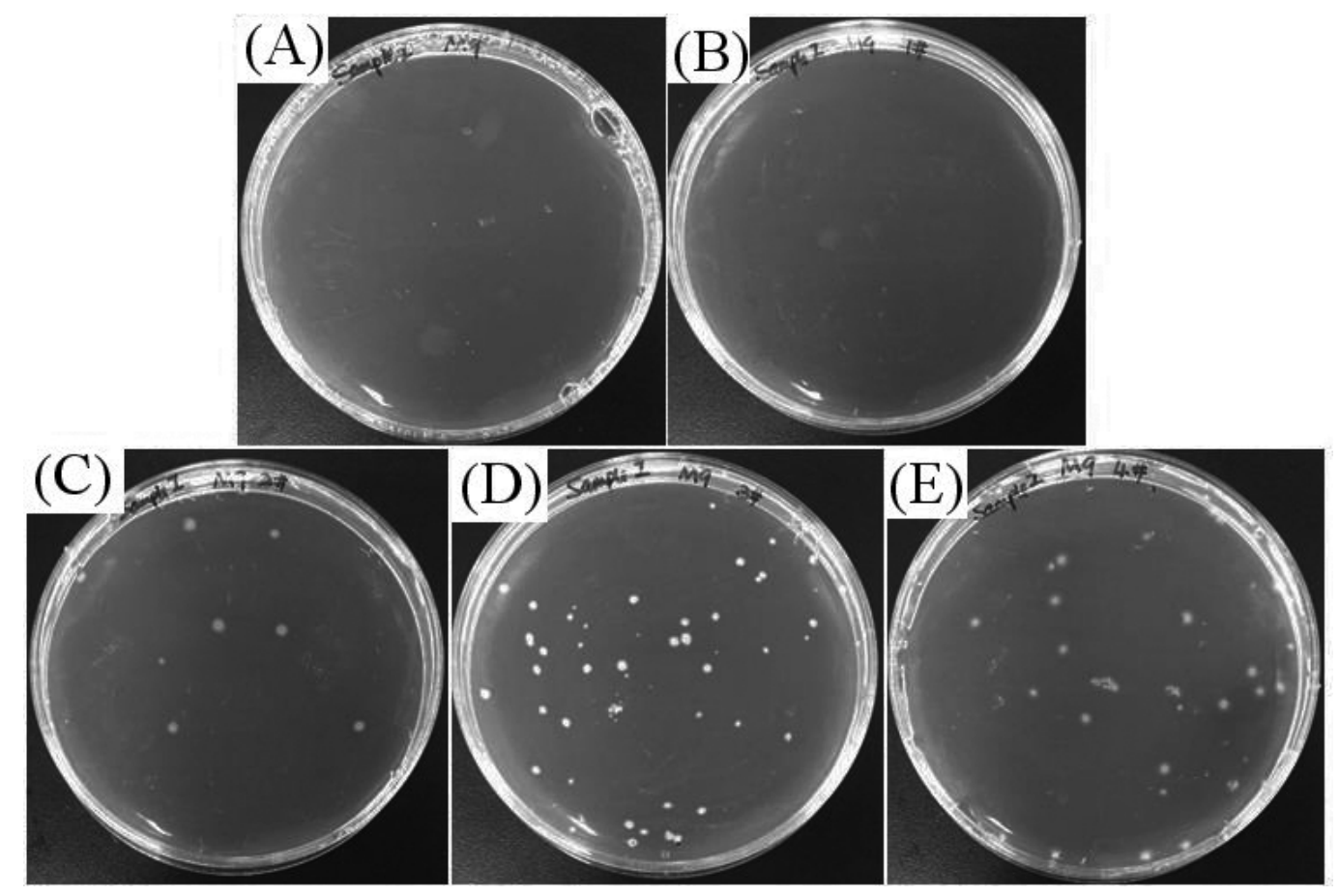

Fig. S4. PA14 persister cell resuscitation on groups of five amino acids. PA14 persister cells were grown for $48 \mathrm{~h}$ on M9 agar plate supplemented with different combinations of five amino acids as the sole carbon source: (A) M9 minimal medium plates without amino acids; (B) M9 with combination \#1; (C) M9 with combination \#2; (D) M9 with combination \#3; and (E) M9 with combination \#4. Specific cell numbers are shown in Table S1. 
bioRxiv preprint doi: https://doi.org/10.1101/674978; this version posted June 18, 2019. The copyright holder for this preprint (which was not certified by peer review) is the author/funder, who has granted bioRxiv a license to display the preprint in perpetuity. It is made available under aCC-BY-NC-ND 4.0 International license.

(A)
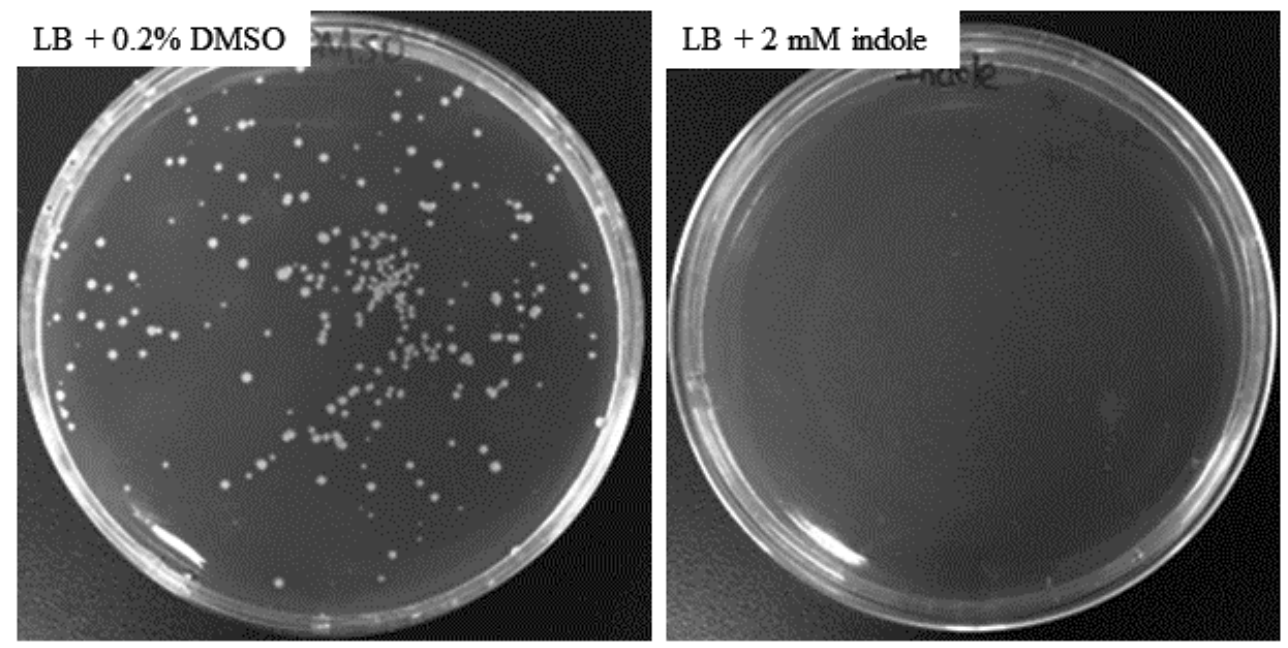

(B)
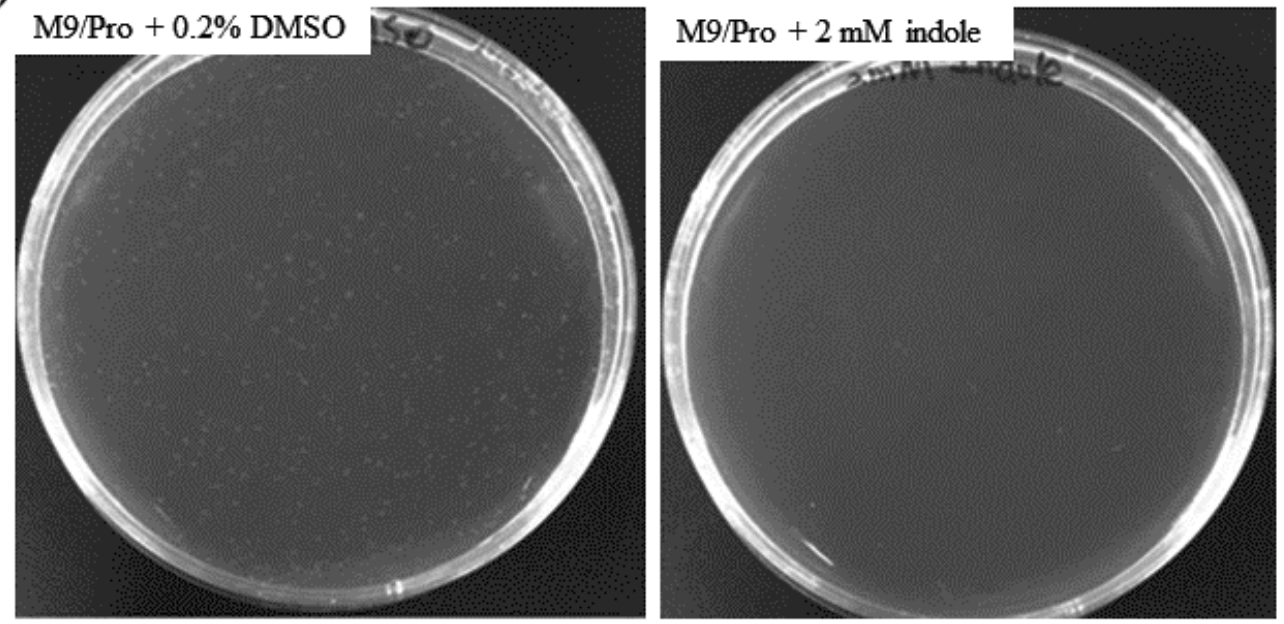

Fig. S5. Indole inhibits PA14 resuscitation. PA14 resuscitation after one day on LB $+0.2 \%$ DMSO and $\mathrm{LB}+2 \mathrm{mM}$ indole (A), and on M9 proline $+0.2 \%$ DMSO and M9 proline $+2 \mathrm{mM}$ indole $(\mathbf{B})$. 

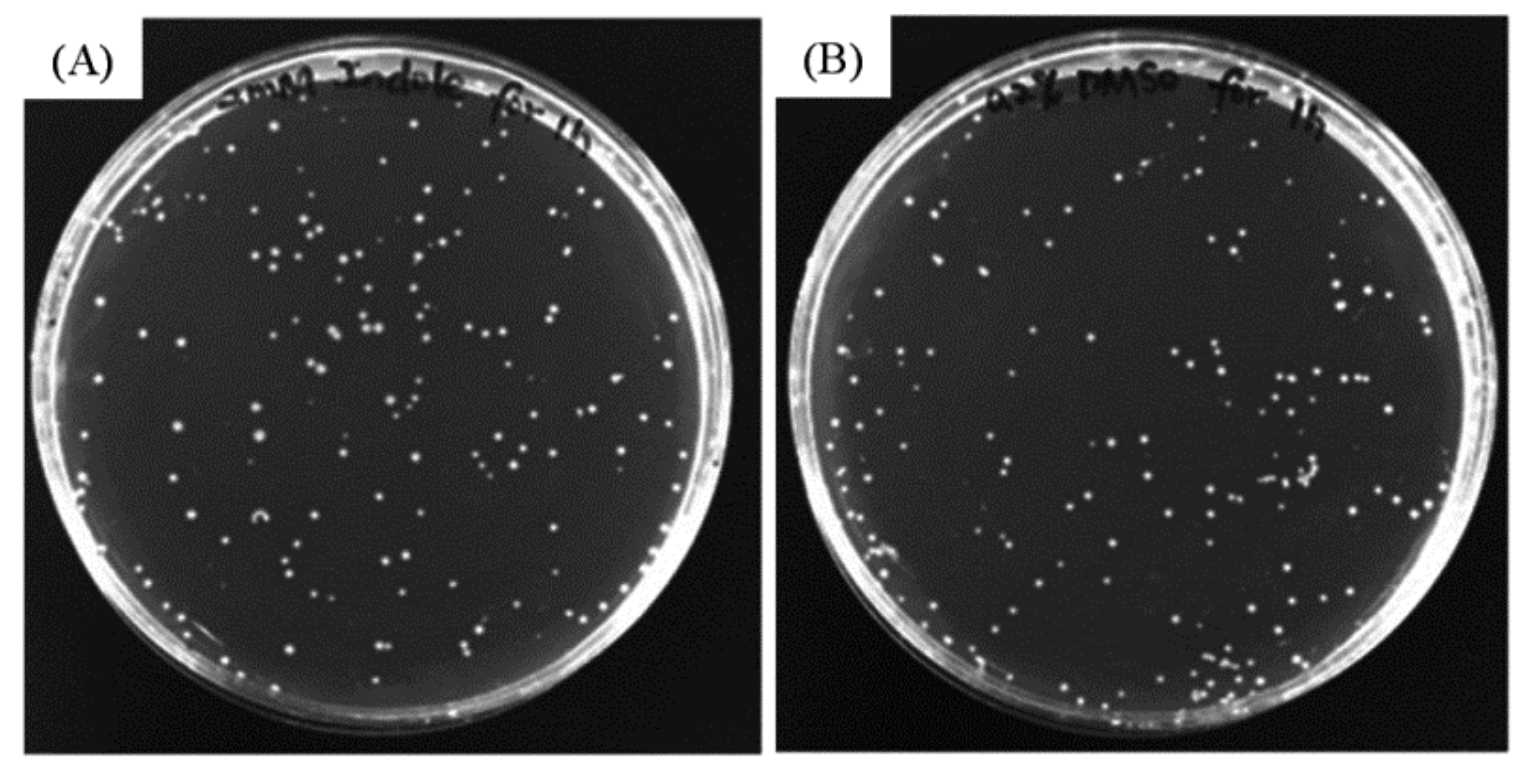

Fig. S6. Indole is not toxic to PA14 persister cells. PA14 persister cells were treated for $1 \mathrm{~h}$ with $2 \mathrm{mM}$ indole $(\mathbf{A})$ and $0.2 \%$ DMSO $(\mathbf{B})$, diluted, and plated $(50 \mu \mathrm{L})$ on LB plates to check for cell viability. 
(A)

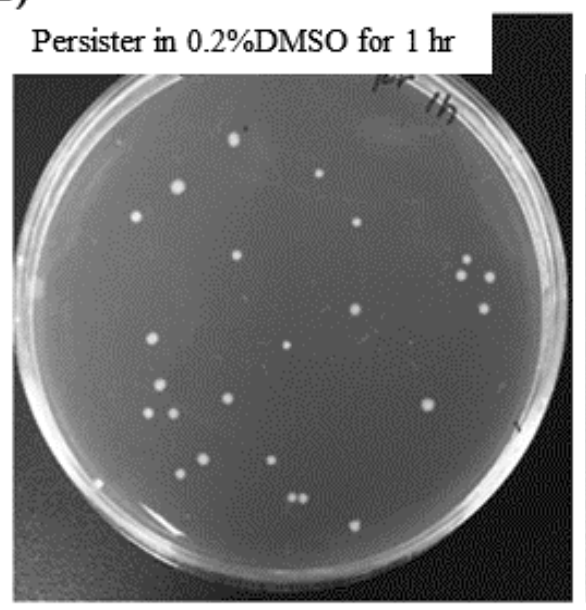
Persister in $2 \mathrm{mM}$ indole for $1 \mathrm{hr}$

(B)

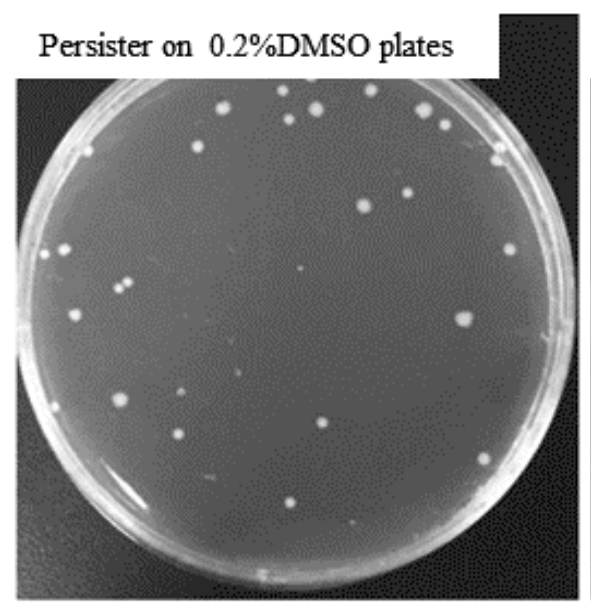
Persister on $2 \mathrm{mM}$ plates

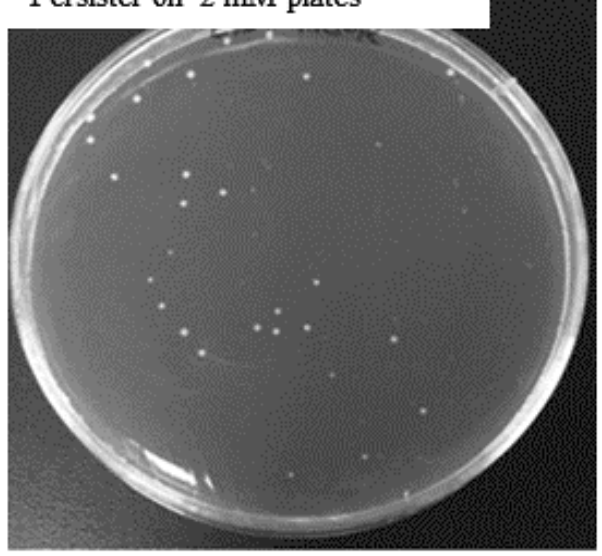

Fig. S7. Indole is not toxic to $E$. coli persister cells. (A) E. coli persister cells were treated with $2 \mathrm{mM}$ indole or $0.2 \%$ DMSO for $1 \mathrm{~h}$, diluted, and plated $(50 \mu \mathrm{L})$ on LB plates. (B) Resuscitation of $E$. coli persister cells on $\mathrm{LB}+0.2 \% \mathrm{DMSO}$ and $\mathrm{LB}+2 \mathrm{mM}$ indole plates. 